

\title{
Catalytic Oxidation of Chlorinated Organics over Lanthanide Perovskites: Eff ects of Phosphoric Acid Etching and Water Vapor on Chlorine Desorption Behavior
}

\author{
Xiaole Weng, ${ }^{\dagger}{ }^{\circledR}$ Qingjie Meng, ${ }^{\dagger}$ Jiajia Liu, ${ }^{\dagger}$ Weiyu Jiang, ${ }^{\dagger}$ Samuel Pattisson, ${ }^{\S}$ and Zhongbiao $\mathrm{Wu}^{*}, \dagger, \pm \odot$ \\ ${ }^{\dagger}$ Key Laboratory of Environment Remediation and Ecological Health, Ministry of Education, College of Environmental \\ and Resource Sciences, Zhejiang University, 310058 Hangzhou, P. R. China

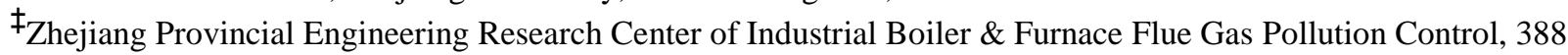 \\ Yuhangtang Road, 310058 Hangzhou, P. R. China

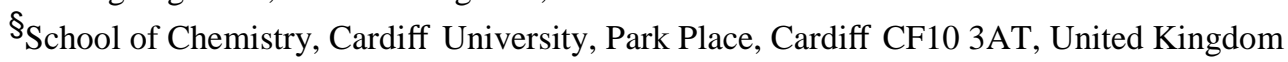 \\ * Supporting Information
}

\begin{abstract}
In this article, the underlying effect of phosphoric acid etching and additional water vapor on chlorine desorption behavior over a model catalyst $\mathrm{La}_{3} \mathrm{Mn}_{2} \mathrm{O}_{7}$ was explored. Acid treatment led to the formation of $\mathrm{LaPO}_{4}$ and enhanced the mobility of lattice oxygen of $\mathrm{La}_{3} \mathrm{Mn}_{2} \mathrm{O}_{7}$ evidenced by a range of characterization (i.e., X-ray diff raction, temperature-programmed analyses, $\mathrm{NH}_{3}-\mathrm{IR}$, etc.). The former introduced thermally stable Brönsted acidic sites that enhanced dichloromethane (DCM) hydrolysis while the latter facilitated desorption of accumulated chlorine at elevated temperatures. The acid-modified catalyst displayed a superior catalytic activity in DCM oxidation compared to the untreated sample, which was ascribed to the abundance of proton donors and $\mathrm{Mn}(\mathrm{IV})$ species. The addition of water

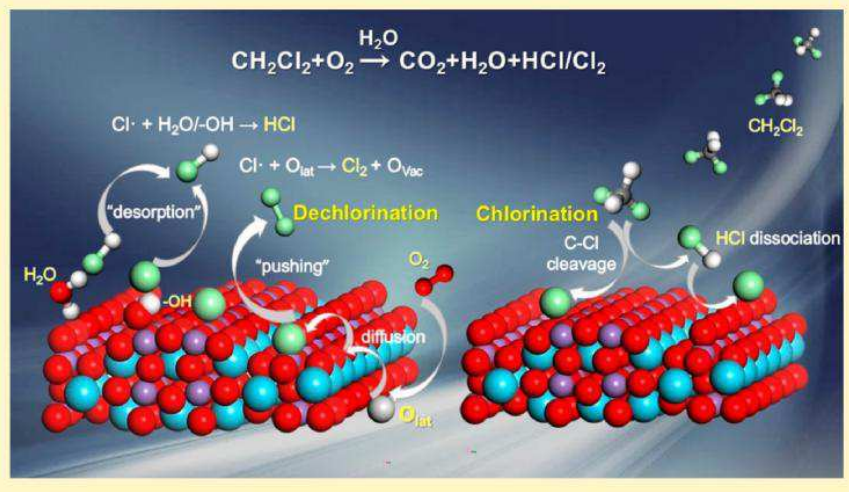
vapor to the reaction favored the formation and desorption of $\mathrm{HCl}$ and avoided surface chlorination at low temperatures. This resulted in a further reduction in reaction temperature under humid conditions ( $\mathrm{T} 90$ of $380{ }^{\circ} \mathrm{C}$ for the modified catalyst). These results provide an in-depth interpretation of chlorine desorption behavior for DCM oxidation, which should aid the future design of industrial catalysts for the durable catalytic combustion of chlorinated organics.
\end{abstract}

\section{INTRODUCTION}

Chlorinated volatile organic compounds (CVOCs) are well-known to have deleterious effects on human health because of their inherent bioaccumulation and potential carcinogenicity; many CVOCs have been listed as priority pollutants worldwide. ${ }^{1,2}$ The efficient catalytic combustion of CVOCs usually encounters the problem of the lack of reliable catalysts to ensure durable operation in industrial applications. In general, there are two steps involved in CVOC oxidation: the scission of the $\mathrm{C}-\mathrm{Cl}$ bond (i.e., adsorption/hydrolysis) at acidic sites or superficial oxygen vacancies, followed by the deep oxidation of adsorbates/intermediates at redox sites. ${ }^{3,4}$ The first step, however, tends to cause reversible or irreversible deactivation of the applied catalysts through surface chlorina-tion. Therefore, efficient chlorine desorption from the applied catalyst is integral to the durable operation of catalytic CVOC oxidation in industry, and the study of chlorine desorption behavior to guide catalyst design is highly required.

Rare earth perovskites have been widely studied in CVOC oxidation due to their favorable structural and thermal stability which makes them well suited to thermocatalysis under industrial conditions (i.e., thermal shock, chlorine poisoning, water vapor, etc.). Many efforts have been devoted to improving redox abilities and surface acidities via substitution of $\mathrm{A} / \mathrm{B}$ cations, ${ }^{5,6}$ introduction of acidic supports (i.e., $\mathrm{Al}_{2} \mathrm{O}_{3}$, $\mathrm{TiO}_{2}$, acidic zeolite $)^{7}$ and loading noble metals. ${ }^{8}$ The deactivation of rare earth perovskites, particularly lanthanide perovskites, has been reported to be caused by the interaction with dissociated chlorine. This has been found to accelerate the lanthanum migration to the surface, leading to the formation of inactive LaOCl. $^{9}$ The inhibited redox ability by surface chlorination was another factor considered to be the cause of deactivation. ${ }^{10}$ To date, there is little knowledge on how to facilitate desorption of chlorine (in the form of either $\mathrm{HCl}$ or $\mathrm{Cl}_{2}$ ) from lanthanide perovskites. In addition, the concentrated water vapor in industrial waste gases is reported to compete with reactants or become aggregated as clusters 
that block the access of applied catalysts to reactants, therefore leading to catalytic deactivation. ${ }^{11-13}$ However, the underlying effect of water vapor on the chlorine desorption behavior still lacks unified interpretation. As such, the deactivation behavior of lanthanide perovskites in CVOC oxidation (with or without water vapor) still requires further exploration, with the aim to clarify their causes and guide the catalyst design for industrial applications.

In this article, a Manganite layered perovskite $\left(\mathrm{La}_{3} \mathrm{Mn}_{2} \mathrm{O}_{7+\delta}\right)$ with high thermal stability and enriched oxygen species was studied as a model catalyst. Phosphoric acid etching was conducted to form insoluble lanthanum phosphate $\left(\mathrm{LaPO}_{4}\right.$, a solid acid that has unique characters in thermal stability,

Bronsted acidity and hydrophilia. ) and expose Mn species at the surface. Unlike the $\mathrm{HNO}_{3}$ and $\mathrm{HF}$ treatment, ${ }^{17,18}$ the $\mathrm{H}_{3} \mathrm{PO}_{4}$ etching could induce excess phosphorus and acidity by coordination of phosphorus species via the hydroxyl groups. ${ }^{19}$ Phosphoric acid treatment has been previously applied to $\mathrm{Pt} /$ MCM-41 to study its eff ect on Pt species. It was found that the increased acidity and oxidized Pt benefited CVOC oxidation. In this paper, phosphoric acid was expected to remove superficial $\mathrm{La}$ cations and form a combined catalyst $\left(\mathrm{LaPO}_{4}-\right.$ $\mathrm{La}_{3} \mathrm{Mn}_{2} \mathrm{O}_{7}$ ) that might benefit chlorine desorption (via the formation of $\mathrm{HCl}$ ) and divert water molecules from active sites in catalytic CVOC oxidation. The aim was to explore the effect of phosphoric acid etching and water vapor on chlorine desorption behavior.

A range of analytical techniques have been employed to reveal the structural and chemical properties of fresh and used catalysts in catalytic dichloromethane (DCM) oxidation (note: the DCM is a typical chlorinated organic that is abundant in the pharmaceutical industry exhaust gas). The behavior of the chlorine desorption and the solid-gas-liquid reaction (to simulate industrial operation condition) was analyzed.

\section{EXPERIMENTAL PROCEDURE}

2.1. Preparation of the Catalyst. The $\mathrm{La}_{3} \mathrm{Mn}_{2} \mathrm{O}_{7+\delta}$ catalyst was synthesized using a modified citric acid route as reported by $\mathrm{Du}$ et al., ${ }^{20}$ denoted as $\mathrm{La}_{3} \mathrm{Mn}_{2} \mathrm{O}_{7}$ (details are provide in Section S1 in the Supporting Information (SI)). The acid modification was conducted by treating portions (1

g) of $\mathrm{La}_{3} \mathrm{Mn}_{2} \mathrm{O}_{7}$ in a $30 \mathrm{~mL}$ of $0.1 \mathrm{M} \mathrm{H}_{3} \mathrm{PO}_{4}$ solution with ultrasonic shaking for $40 \mathrm{~min}$ at room temperature. The solid products were washed with deionized water three times and then dried in a vacuum oven at $40{ }^{\circ} \mathrm{C}$ for $24 \mathrm{~h}$. The resulting sample was denoted as $\mathrm{La}_{3} \mathrm{Mn}_{2} \mathrm{O}_{7}-\mathrm{P}$.

2.2. Characterization of Catalysts. Details of character-ization techniques, including XRD, HR-TEM, XPS, DRIFTS, TPR/TPD, etc. are provided in SI Section S2. Temperature-programmed desorption (TPD), temperature-programmed reduction (TPR) and temperatureprogrammed surface reaction (TPSR) were conducted using an automatic multi-purpose adsorption instrument TP-5079 (Tianjin Xianquan, China) equipped with a thermal conductivity detector (TCD) and a portable mass spectrograph (MS) QGA (Hiden Analytical, UK).

Density functional theory (DFT) study was performed using the Vienna ab initio Simulation Package (VASP-5.4). ${ }^{21}$ A plane-wave basis set with a cutoff energy of $400 \mathrm{eV}$ within the framework of the projector-augmented wave (PAW) method was employed. Each atom was converged to $0.05 \mathrm{eV}^{-1}$ for geometry optimization. A unit cell $(\mathrm{a}=\mathrm{b}=3.98 \AA, \mathrm{c}=20.92$ $\AA)$ with 24 atoms $(6 \mathrm{La}, 4 \mathrm{Mn}, 14 \mathrm{O})^{20}$ and a $2 \times 2 \times 1$ supercell with 96 atoms was used as the modeled catalyst $\mathrm{La}_{3} \mathrm{Mn}_{2} \mathrm{O}_{7}$. A $3 \times 3 \times 1$ Monkhorst-pack k-point mesh for geometry optimization of the $\mathrm{La}_{3} \mathrm{Mn}_{2} \mathrm{O}_{7}$ composites was applied. Lanthanum etching was simulated by removing all the La atoms deposited at the exposed facet (1 0 0 0) (SI Figure S1).

2.3. Catalytic Test. The catalytic activities were evaluated in terms of $\mathrm{DCM}$ and $\mathrm{CO}_{2} / \mathrm{CO}$ conversion as a function of temperature. The feed gas $(100 \mathrm{~mL} / \mathrm{min})$ was comprised of 0.1 vol \% DCM, 10 vol \% oxygen and $\mathrm{N}_{2}$ (as the inert diluent gas and/or carrier gas for steam), giving a constant gas hourly space velocity (GHSV) of $12000 \mathrm{~mL}$ $\mathrm{g}^{-1} \mathrm{~h}^{-1}$. The decomposition of DCM by homogeneous gas reactions was neglected for temperatures under $600{ }^{\circ} \mathrm{C}$, and the character-istic $\mathrm{T}_{\mathrm{x}}$ (the temperature when $\mathrm{x} \% \mathrm{DCM}$ conversion or $\mathrm{CO}_{2}$ generation was reached in the light-off curves) was used as an indicator for activity. Conversion data were collected after an initial period of $40 \mathrm{~min}$ for each temperature to obtain a nearly constant reaction rate. The desorption plot of $\mathrm{HCl}$ or $\mathrm{Cl}_{2}$ was recorded using $\mathrm{MS}$. Further details are provided in SI Section S2.

\section{RESULTS AND DISCUSSION}

3.1. XRD, Surface Area, and HR-TEM Measurements. As identified through XRD analyses (SI Figure S2), trace amount of $\mathrm{LaPO}_{4} \cdot 0.5 \mathrm{H}_{2} \mathrm{O}$ (JCPDS 46-1439) with the characteristic reflections at $2 \theta$ of $19.9^{\circ}, 25.1^{\circ}, 29.0^{\circ}, 31.2^{\circ}$, and $48.1^{\circ}$ was observed in $\mathrm{La}_{3} \mathrm{Mn}_{2} \mathrm{O}_{7+\delta}-\mathrm{P}$ apart from the main structure of $\mathrm{La}_{3} \mathrm{Mn}_{2} \mathrm{O}_{7}$. This result implied that a reaction between the surface $\mathrm{La}^{3+}$ cations and $\mathrm{PO}_{4}{ }^{3-}$ occurred during the phosphoric acid etching generating insoluble $\mathrm{LaPO}_{4}$. $0.5 \mathrm{H}_{2} \mathrm{O}$. Surface area measurements demonstrated that each catalyst displayed a type II $\mathrm{N}_{2}$ adsorption-desorption isotherm with a $\mathrm{H}_{3}$-type hysteresis loop in the relative pressure $\left(\mathrm{p}_{\mathrm{p}} / \mathrm{p}_{0}\right)$ range of $0.2-1.0$ (SI Figure S3), thereby revealing the existence of slit pores (originating from particles stacking) in $\mathrm{La}_{3} \mathrm{Mn}_{2} \mathrm{O}_{7}$ and $\mathrm{La}_{3} \mathrm{Mn}_{2} \mathrm{O}_{7}-\mathrm{P}^{22}{ }^{22}$ The phosphoric acid treatment was found to increase the surface area from approximately $18.8 \mathrm{~m}^{2} \mathrm{~g}^{-1}$ (for $\mathrm{La}_{3} \mathrm{Mn}_{2} \mathrm{O}_{7}$ ) to $90.1 \mathrm{~m}^{2} \mathrm{~g}^{-1}$ (for $\mathrm{La}_{3} \mathrm{Mn}_{2} \mathrm{O}_{7}-\mathrm{P}$ ). This increment was attributed to the reduction of particle size (from 24 to $35 \mathrm{~nm}$ ), accompanied by the enlargement of pore size (from 8.9 to $15 \mathrm{~nm}$, SI Table S1) and the formation of $\mathrm{LaPO}_{4} \cdot 0.5 \mathrm{H}_{2} \mathrm{O}$. As evidenced in HRTEM analyses (SI Figure S4), the $\mathrm{La}_{3} \mathrm{Mn}_{2} \mathrm{O}_{7}$ displayed uniform spherical particles with a size of $35 \pm 7 \mathrm{~nm}$ (based on 150 particles, as shown in the size distribution), whereas the $\mathrm{La}_{3} \mathrm{Mn}_{2} \mathrm{O}_{7}-\mathrm{P}$ was characterized by much smaller spherical particles of $24 \pm 5 \mathrm{~nm}$, tangled with needle-like crystals that were characteristic of rhabdophane $\mathrm{LaPO}_{4} \cdot 0.5 \mathrm{H}_{2} \mathrm{O} .{ }^{23,24}$ After being subjected to DCM oxidation, the structures of both $\mathrm{La}_{3} \mathrm{Mn}_{2} \mathrm{O}_{7}$ and $\mathrm{La}_{3} \mathrm{Mn}_{2} \mathrm{O}_{7}-\mathrm{P}$ were not changed, and no phase of $\mathrm{MnCl}_{x}, \mathrm{MnO}_{x} \mathrm{Cl}_{y}$, or $\mathrm{LaOCl}$ was identified. Although the decrease in surface area was observed for both used catalysts, the surface area of the $\mathrm{La}_{3} \mathrm{Mn}_{2} \mathrm{O}_{7}-\mathrm{P}$ catalyst (ca. $63 \mathrm{~m}^{2} \mathrm{~g}^{-1}$ ) was still six times higher than that of $\mathrm{La}_{3} \mathrm{Mn}_{2} \mathrm{O}_{7}$ (ca. $9 \mathrm{~m}^{2}$ $\left.\mathrm{g}^{-1}\right)$. This result was consistent with the report that the phosphate treatment could inhibit the crystal grain growth of oxides at elevated temperatures. ${ }^{25}$ As a sufficient contact area between reactants and catalyst is important for effective catalytic oxidation, ${ }^{26}$ the large increment in the surface area of $\mathrm{La}_{3} \mathrm{Mn}_{2} \mathrm{O}_{7}-\mathrm{P}$ would be expected to provide higher access to reactants such as DCM, oxygen and water molecules, and therefore result in superior activity. 

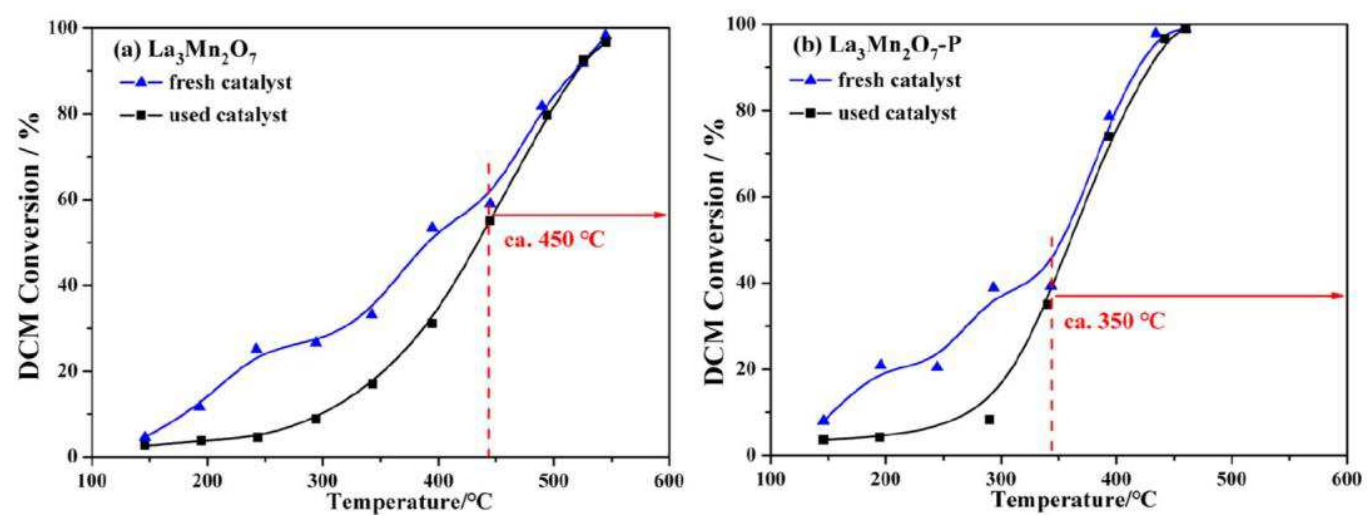

Figure 1. Light-off curves of DCM oxidation over the fresh and used (a) $\mathrm{La}_{3} \mathrm{Mn}_{2} \mathrm{O}_{7}$ and (b) $\mathrm{La}_{3} \mathrm{Mn}_{2} \mathrm{O}_{7}-\mathrm{P}$ catalysts.
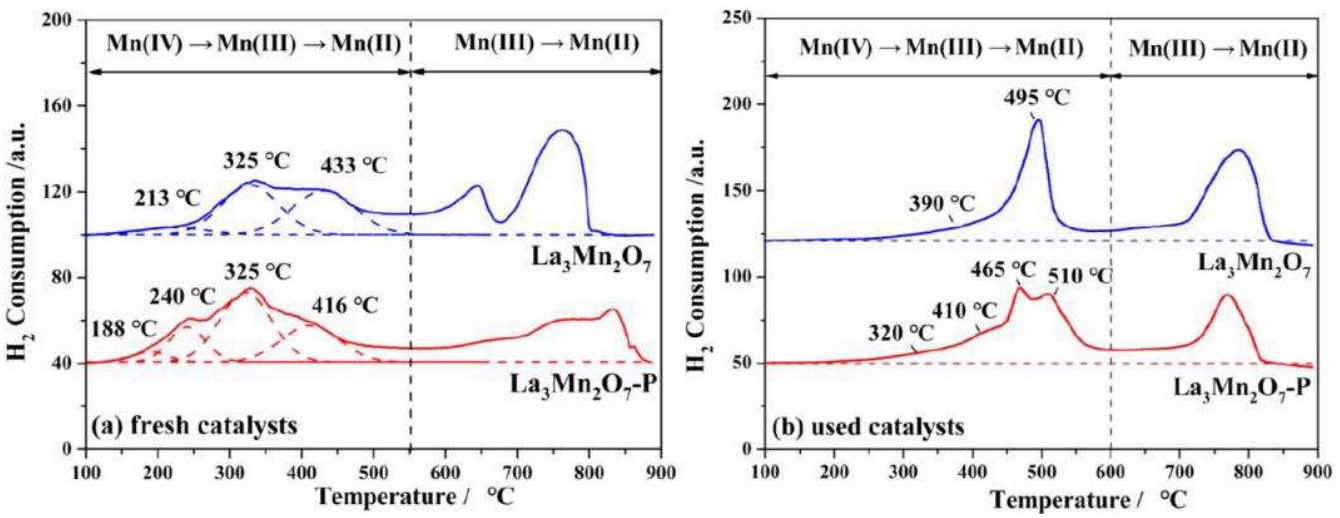

Figure 2. $\mathrm{H}_{2}$-TPR profiles of the (a) fresh and (b) used catalysts $\mathrm{La}_{3} \mathrm{Mn}_{2} \mathrm{O}_{7}$ and $\mathrm{La}_{3} \mathrm{Mn}_{2} \mathrm{O}_{7}-\mathrm{P}$. The first peak at $200-600{ }^{\circ} \mathrm{C}$ is related to the reduction of reactive oxygen species or manganese species with higher valence states, and the second peak at $600-900{ }^{\circ} \mathrm{C}$ corresponds to further reduction of $\mathrm{Mn}(\mathrm{III})$ to $\mathrm{Mn}(\mathrm{II})$.

3.2. Catalytic Activity Measurements. The light-off curves of DCM oxidation over the $\mathrm{La}_{3} \mathrm{Mn}_{2} \mathrm{O}_{7}$ and $\mathrm{La}_{3} \mathrm{Mn}_{2} \mathrm{O}_{7}-$

$\mathrm{P}$ catalysts are illustrated in Figure 1 . For $\mathrm{La}_{3} \mathrm{Mn}_{2} \mathrm{O}_{7}$, the $\mathrm{T}_{50}$ over the used sample (at ca. $435^{\circ} \mathrm{C}$ ) was $45^{\circ} \mathrm{C}$ higher than that of the fresh counterpart (at ca. $390^{\circ} \mathrm{C}$ ). Such an obvious decline in DCM conversion over the used catalyst indicated that $\mathrm{La}_{3} \mathrm{Mn}_{2} \mathrm{O}_{7}$ experienced deactivation due to chlorine poisoning. In comparison, a distinct promotion in the catalytic activity of the acid-modified catalyst $\mathrm{La}_{3} \mathrm{Mn}_{2} \mathrm{O}_{7}-\mathrm{P}$ was observed, revealing a consistent $\mathrm{T}_{50}$ of DCM conversion at $355^{\circ} \mathrm{C}$ and a much lower T90 at $420^{\circ} \mathrm{C}$ over the fresh and used catalysts. A decline in DCM conversion was still observed over $\mathrm{La}_{3} \mathrm{Mn}_{2} \mathrm{O}_{7}-\mathrm{P}$, however the transition temperature related to $\mathrm{Cl}$ poisoning was much lower than that of $\mathrm{La}_{3} \mathrm{Mn}_{2} \mathrm{O}_{7}$ (ca.

${ }^{\circ} \mathrm{C}$ for $\mathrm{La}_{3} \mathrm{Mn}_{2} \mathrm{O}_{7}-\mathrm{P}$ and ca. $450{ }^{\circ} \mathrm{C}$ for $\mathrm{La}_{3} \mathrm{Mn}_{2} \mathrm{O}_{7}$ ). The350 result suggested the eff ect of chlorine poisoning on $\mathrm{La}_{3} \mathrm{Mn}_{2} \mathrm{O}_{7}-\mathrm{P}$ was confined to a narrower reaction temperature window. In both catalysts, the vast majority of DCM was found to be converted into $\mathrm{CO}_{2}$, with $\mathrm{La}_{3} \mathrm{Mn}_{2} \mathrm{O}_{7}-\mathrm{P}$ demonstrating a particularly high $\mathrm{CO}_{2}$ selectivity (SI Figure S5).

3.3. $\mathrm{H}_{2}$-TPR and XPS Analyses. Analysis of the fresh $\mathrm{La}_{3} \mathrm{Mn}_{2} \mathrm{O}_{7}$ catalyst by $\mathrm{H}_{2}$-TPR (Figure 2), revealed three $\mathrm{H}_{2}$ consumption peaks centered at approximately 213,325, and $433{ }^{\circ} \mathrm{C}$. The peak at $213{ }^{\circ} \mathrm{C}$ originated from the reaction between $\mathrm{H}_{2}$ and chemisorbed oxygen; the peak at $325{ }^{\circ} \mathrm{C}$ corresponds to the reduction of Mn(IV) to $\mathrm{Mn}(\mathrm{III})$ and that at $433{ }^{\circ} \mathrm{C}$ is assigned to the single-electron reduction of $\mathrm{Mn}$ (III) located in the coordination-unsaturated microenvironment. $^{27,28}$ The fresh $\mathrm{La}_{3} \mathrm{Mn}_{2} \mathrm{O}_{7}-\mathrm{P}$ catalyst displayed peaks at approximately 188,325 , and $416{ }^{\circ} \mathrm{C}$, all of which were much lower than those of $\mathrm{La}_{3} \mathrm{Mn}_{2} \mathrm{O}_{7}$. The improved redox ability of $\mathrm{La}_{3} \mathrm{Mn}_{2} \mathrm{O}_{7}-\mathrm{P}$ was proposed to be attributed to the increased surface area, the exposure of Mn species and the enhancement in lattice oxygen mobility, as will be verified later. The additional peak at $240{ }^{\circ} \mathrm{C}$ was believed to originate from the reduction of exposed Mn(IV) species caused by lanthanum etching. 18

For the used catalysts, the $\mathrm{H}_{2}$ reduction peaks both shifted toward higher temperature range, implying that the redox ability of the catalyst was inhibited after DCM oxidation. In particular, most of the $\mathrm{Mn}(\mathrm{IV})$ (at ca. $390{ }^{\circ} \mathrm{C}$ in Figure 2(b)) in the $\mathrm{La}_{3} \mathrm{Mn}_{2} \mathrm{O}_{7}$ was found to be reduced to $\mathrm{Mn}$ (III) (at ca. 495 ${ }^{\circ} \mathrm{C}$ in Figure 2(b)). This result suggested that the dissociative chlorine interacted with the Mn(IV) species (Lewis acidic sites) and reduced the $\mathrm{Mn}$ valence. In contrast, the used $\mathrm{La}_{3} \mathrm{Mn}_{2} \mathrm{O}_{7}-\mathrm{P}$ displayed a retained low-temperature redox ability with most of the active oxygen and Mn(IV) species (centered at $320{ }^{\circ} \mathrm{C}, 410$ and $465{ }^{\circ} \mathrm{C}$ in Figure 2(b)) still present. This result suggested that the chlorine might be eff ectively desorbed from the catalyst surface that possessed the Mn(IV). Indeed, XPS measurements on the used catalyst revealed that the used $\mathrm{La}_{3} \mathrm{Mn}_{2} \mathrm{O}_{7}-\mathrm{P}$ had ca. $5 \%$ residual $\mathrm{Cl}$ on the surface, that is, much lower than the used $\mathrm{La}_{3} \mathrm{Mn}_{2} \mathrm{O}_{7}$ (at ca. $14.8 \%$ ).

In the literature, ${ }^{9,10,29} \mathrm{Mn}(\mathrm{IV})$ was proposed to be the most active species for low-temperature CVOC oxidation. Here, the regeneration of $\mathrm{Mn}(\mathrm{IV})-\mathrm{O}$ center via chlorine removal was considered to be the rate-determining step for CVOC 

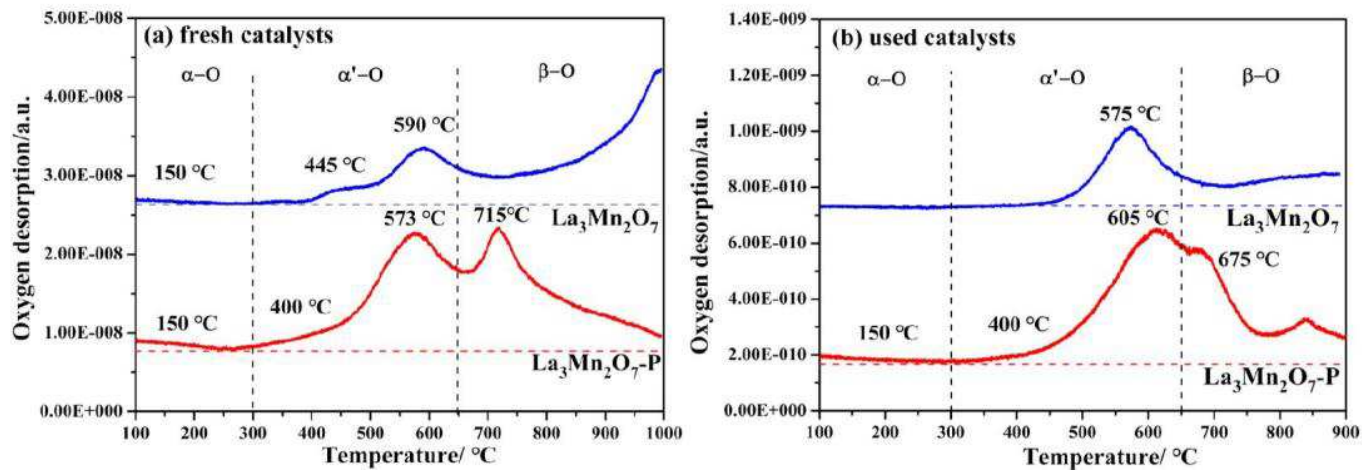

Figure 3. $\mathrm{O}_{2}-\mathrm{TPD}$ profiles of (a) $\mathrm{La}_{3} \mathrm{Mn}_{2} \mathrm{O}_{7}$ and (b) $\mathrm{La}_{3} \mathrm{Mn}_{2} \mathrm{O}_{7}-\mathrm{P}$ catalysts. Three types of oxygen species were cataloged as $\alpha-\mathrm{O}$, $\alpha^{\prime}-\mathrm{O}$, and $\beta-\mathrm{O}$, depending on the maximum temperatures.
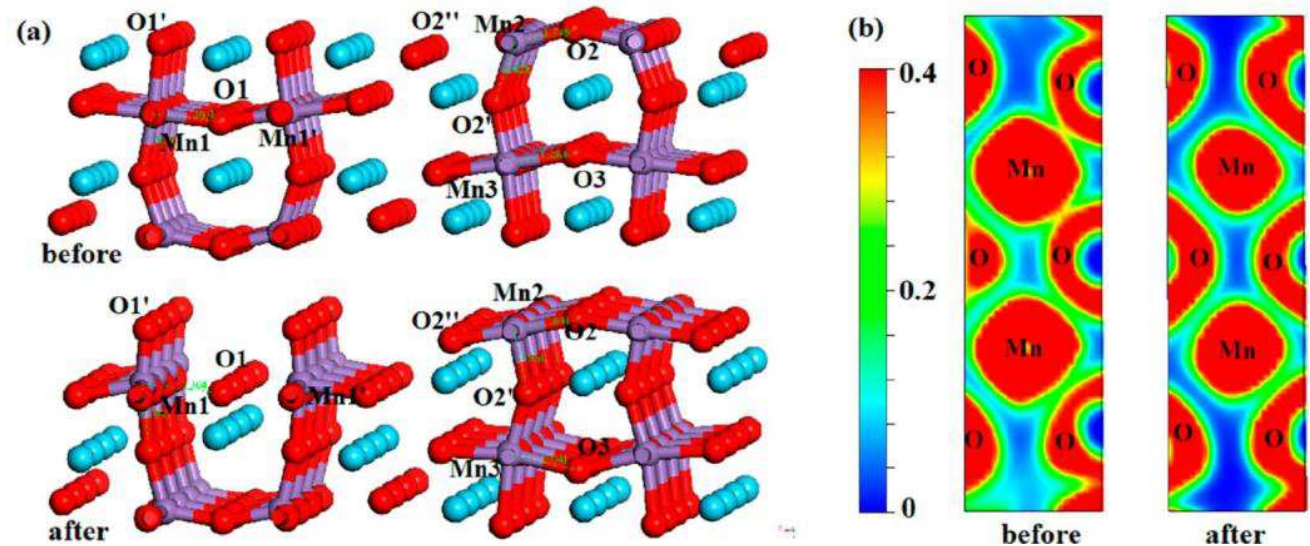

Figure 4. (a) DFT calculation on the $\mathrm{Mn}-\mathrm{O}$ bond distance for lanthanide perovskite before and after lanthanum etching at the surficial lanthanum-rich layer and (b) the electronic localization function (ELF) of Mn sites deposited at facet (010).

oxidation. In general, a dual active center was involved in the CVOC oxidation process over perovskites: an acidic site (electrophile) for attacking chlorine, and a basic site (nucleophile) for attacking carbon, followed by the adsorbates being oxidized at redox sites to form $\mathrm{CO}_{2}$ and $\mathrm{H}_{2} \mathrm{O}$. In $\mathrm{La}_{3} \mathrm{Mn}_{2} \mathrm{O}_{7}$, the $\mathrm{Mn}(\mathrm{IV})-\mathrm{O}$ species acted as both the adsorption center and redox site. As such, the accumulation of dissociated chlorine on the redox site that led to the reduction of $\mathrm{Mn}$ (IV) to $\mathrm{Mn}(\mathrm{III})$ would cause catalyst deactivation.

XPS analysis of the fresh $\mathrm{La}_{3} \mathrm{Mn}_{2} \mathrm{O}_{7}$ catalyst revealed a lanthanum enrichment feature with $40 \%$ La excess on the surface. The semiquantitatively measured $\mathrm{La} / \mathrm{Mn}$ atomic ratio (2.1) was much higher than the theoretical value (1.5). After acidic treatment, a peak at ca. $133.4 \mathrm{eV}$ was observed in the XPS spectra of P 2p (SI Figure S6) which suggested the formation of $\mathrm{LaPO}_{4}$ in $\mathrm{La}_{3} \mathrm{Mn}_{2} \mathrm{O}_{7}-\mathrm{P}$ (with the surface atomic ratio of $\mathrm{La}: \mathrm{Mn}: \mathrm{P}$ at $2.3: 1: 1.1$ ). This resulted in the reduction of the $\mathrm{La} / \mathrm{Mn}$ atomic ratio in the main phase $\mathrm{La}_{3} \mathrm{Mn}_{2} \mathrm{O}_{7}$ to 1.2 (as $\mathrm{LaPO}_{4} \cdot 0.5 \mathrm{H}_{2} \mathrm{O}$ has an atomic ratio $\mathrm{La} / \mathrm{P}$ of 1 ). The even lower $\mathrm{La} / \mathrm{Mn}$ ratio than the theoretical datum suggested that many manganese species had been exposed to the catalyst surface after acid etching. Such an exposure, leading to transition metal-rich termination, is expected to induce enriched oxygen vacancies on the catalyst surface. ${ }^{30}$ Indeed, the $\mathrm{O} 1 \mathrm{~s}$ XPS revealed that the $\mathrm{O}_{\mathrm{ad}} / \mathrm{O}_{\text {lat }}$ atomic ratio in the $\mathrm{La}_{3} \mathrm{Mn}_{2} \mathrm{O}_{7}-\mathrm{P}$ was measured at 1.0, much higher than that of

$\mathrm{La}_{3} \mathrm{Mn}_{2} \mathrm{O}_{7}$ (0.4) (SI Figure S7). Notably, the $\mathrm{La}_{3} \mathrm{Mn}_{2} \mathrm{O}_{7}-\mathrm{P}$ displayed distinct $\mathrm{OH}^{-}$and adsorbed $\mathrm{H}_{2} \mathrm{O}$ species at the surface; these species should originate from the increased surface area and the $\mathrm{P}-\mathrm{OH}$ or water (crystal water or "zeolitic" water ${ }^{24,31}$ ) residing in the $\mathrm{LaPO}_{4} \cdot 0.5 \mathrm{H}_{2} \mathrm{O}$ structure.

3.4. $\mathrm{O}_{2}$-TPD Analyses and DFT Calculations. In the $\mathrm{O}_{2}-$ TPD profile, the desorbed oxygen species can be categorized into chemisorbed oxygen species (a-O) at $100-300{ }^{\circ} \mathrm{C}$, superficial lattice oxygen $\left(\alpha^{\prime}-\mathrm{O}\right.$, including the nonstoichiometric oxygen $\alpha^{\prime \prime}-\mathrm{O}$ ) at $300-600{ }^{\circ} \mathrm{C}$ and bulk lattice oxygen $(\beta-\mathrm{O})$ above $600{ }^{\circ} \mathrm{C}$. As shown in Figure 3(a), the fresh $\mathrm{La}_{3} \mathrm{Mn}_{2} \mathrm{O}_{7}$ displayed three desorption peaks with maxima at approximately $150{ }^{\circ} \mathrm{C}, 590^{\circ} \mathrm{C}$ (with a shoulder at $445^{\circ} \mathrm{C}$ ) and $1000{ }^{\circ} \mathrm{C}$. The low-temperature peak $\alpha-\mathrm{O}$ at $150{ }^{\circ} \mathrm{C}$ was assigned to the oxygen chemisorbed on oxygen vacancies; the $\alpha$ 'O peak at $590{ }^{\circ} \mathrm{C}$ was the superficial lattice oxygen generated from grain boundaries and dislocations, and the shoulder at $445{ }^{\circ} \mathrm{C}$ originated from the over-stoichiometric oxygen $(\alpha "-O)$ in manganese-based layered perovskites. ${ }^{32}$ The $\beta-O$ peak at $1000{ }^{\circ} \mathrm{C}$ was mainly the bulk oxygen desorbed via vacancy migration inwards with the increase of temperature. For $\mathrm{La}_{3} \mathrm{Mn}_{2} \mathrm{O}_{7}-\mathrm{P}$, the oxygen desorption peaks appeared at approximately $150{ }^{\circ} \mathrm{C}, 573^{\circ} \mathrm{C}$ (with a shoulder at $400{ }^{\circ} \mathrm{C}$ ) and $715^{\circ} \mathrm{C}$, all of which experienced a lower temperature shift in comparison with that of $\mathrm{La}_{3} \mathrm{Mn}_{2} \mathrm{O}_{7}$. In particular, the amounts of $\alpha^{\prime}-\mathrm{O}\left(\alpha^{\prime \prime}-\mathrm{O}\right)$ and $\beta-\mathrm{O}$ were found to be both distinctly increased in the $\mathrm{La}_{3} \mathrm{Mn}_{2} \mathrm{O}_{7}-\mathrm{P}$, suggesting that the acidic treatment had eff ectively improved the lattice oxygen mobility in the catalyst. In the used $\mathrm{La}_{3} \mathrm{Mn}_{2} \mathrm{O}_{7}$, the chemisorbed ( $\alpha-\mathrm{O}$ ) and over-stoichiometric oxygen ( $\left.\alpha^{\prime \prime}-\mathrm{O}\right)$ disappeared, whereas those still existed in the used $\mathrm{La}_{3} \mathrm{Mn}_{2} \mathrm{O}_{7}-\mathrm{P}$. This result indicated that the $\mathrm{La}_{3} \mathrm{Mn}_{2} \mathrm{O}_{7}-\mathrm{P}$ had a better redox cycle in 

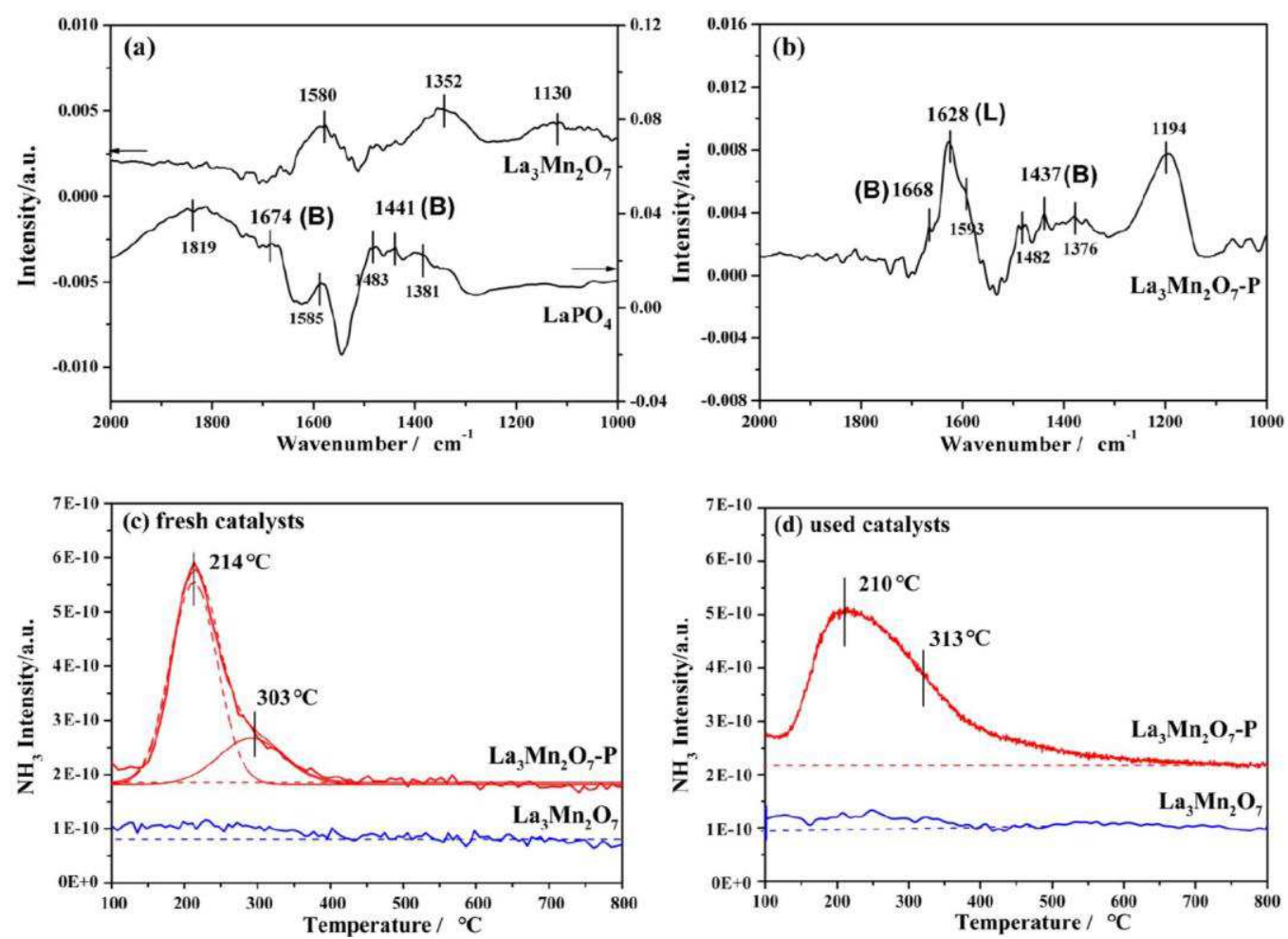

Figure 5. (a,b) $\mathrm{NH}_{3}-\mathrm{IR}$ spectra of the fresh $\mathrm{La}_{3} \mathrm{Mn}_{2} \mathrm{O}_{7}, \mathrm{LaPO}_{4}$ (derived from the reaction of $\mathrm{La}\left(\mathrm{NO}_{3}\right)_{3}$ and $\left.\mathrm{H}_{3} \mathrm{PO}_{4}\right)$ and $\mathrm{La}_{3} \mathrm{Mn}_{2} \mathrm{O}_{7}-\mathrm{P}$ catalysts; (c,-d) $\mathrm{NH}_{3}-\mathrm{TPD}$ profiles of the fresh and used catalysts $\mathrm{La}_{3} \mathrm{Mn}_{2} \mathrm{O}_{7}$ and $\mathrm{La}_{3} \mathrm{Mn}_{2} \mathrm{O}_{7}-\mathrm{P}$. The signal of $\mathrm{NH}_{3}$ desorption was recorded using $\mathrm{MS}(\mathrm{m} / \mathrm{z}=16)$.
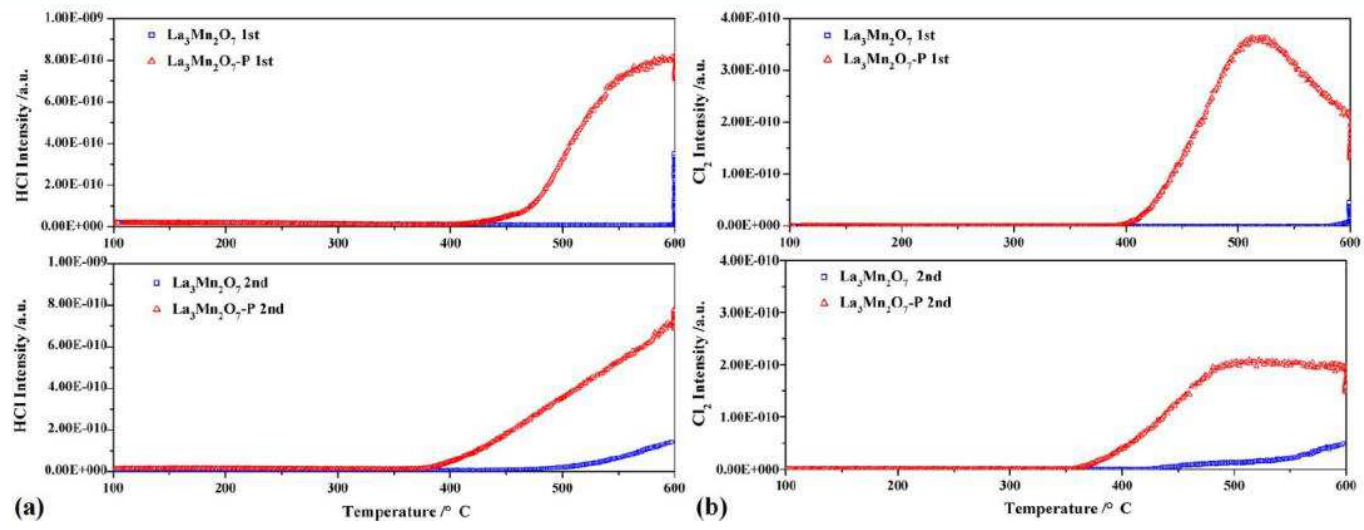

Figure 6. DCM-TPSR profiles of (a) $\mathrm{HCl}$ and (b) $\mathrm{Cl}_{2}$ desorption for $\mathrm{La}_{3} \mathrm{Mn}_{2} \mathrm{O}_{7}$ ( $\square$ ) and $\mathrm{La}_{3} \mathrm{Mn}_{2} \mathrm{O}_{7}-\mathrm{P}$ ( ) catalysts in the first and second runs.

DCM oxidation. The ability for efficient chlorine desorption should account for such an enhanced redox cycle. Notably, for the used $\mathrm{La}_{3} \mathrm{Mn}_{2} \mathrm{O}_{7}-\mathrm{P}$ (Figure 3(b)), the peak corresponding to the subsurface lattice oxygen species (at $\left.675^{\circ} \mathrm{C}\right)$ merged into the superficial ones $\left(605^{\circ} \mathrm{C}\right)$. This indicated that the lattice oxygen migrated outwards, leaving vacancies at the subsurface during the DCM oxidation.

DFT calculation was used to verify the enhanced oxygen mobility of the modified catalyst after La etching. After stripping La from the first layer, the exposed oxygen at the surface (i.e., O1' and O2") was found to bond tightly with $\mathrm{Mn}$. However, the oxygen anion at the shared vertex site of two $\mathrm{MnO}_{6}$ (i.e., O1, O2, and $\mathrm{O} 3$ ) was easier to lose with enhanced mobility because of the adjacent $\mathrm{Mn}-\mathrm{O}$ bonds (Mn1-O1) being elongated to ca. $2.304 \AA$ from the original $1.984 \AA$ A. The electronic localization function (ELF, Figure 4b) also confirmed the existence of less covalent interactions between the $\mathrm{Mn}$ sites and their adjacent $\mathrm{O}$ atoms after La removal. According to Kagomiya et al., ${ }^{33,34}$ the oxygen atoms at the shared vertex could be easily liberated at elevated temperatures, leaving oxygen vacancies, which enhanced the mobility of superficial and subsurface oxygen as reflected in $\mathrm{O}_{2}$-TPD profiles. Actually, the La cation was inclined to attract oxygen and elongate the $\mathrm{Mn}-\mathrm{O}$ bond as reported, ${ }^{35}$ so the superficial $\mathrm{Mn}-\mathrm{O}$ bond being released from $\mathrm{La}$ attraction became stronger while those in the second and third layers were weakened due to residual La cations, leading to easier oxygen desorption and facilitated oxygen mobility.

3.5. Surface Acidity Assessment. In the $\mathrm{NH}_{3}-\mathrm{TPD}$ profile, the acidic sites can be generally divided into weak acidity $\left(<200{ }^{\circ} \mathrm{C}\right)$, moderate acidity $\left(200-400{ }^{\circ} \mathrm{C}\right)$ and strong acidity $\left(>400{ }^{\circ} \mathrm{C}\right)$. As shown in Figure 5, the fresh $\mathrm{La}_{3} \mathrm{Mn}_{2} \mathrm{O}_{7}$ displayed a weak ammonia desorption peak below $400{ }^{\circ} \mathrm{C}$ that mainly originated from the Lewis acid sites of $\mathrm{Mn}$ with an 
Scheme 1. The Chlorination and Dechlorination Process for DCM Oxidation over Applied Catalysts ${ }^{\mathrm{a}}$

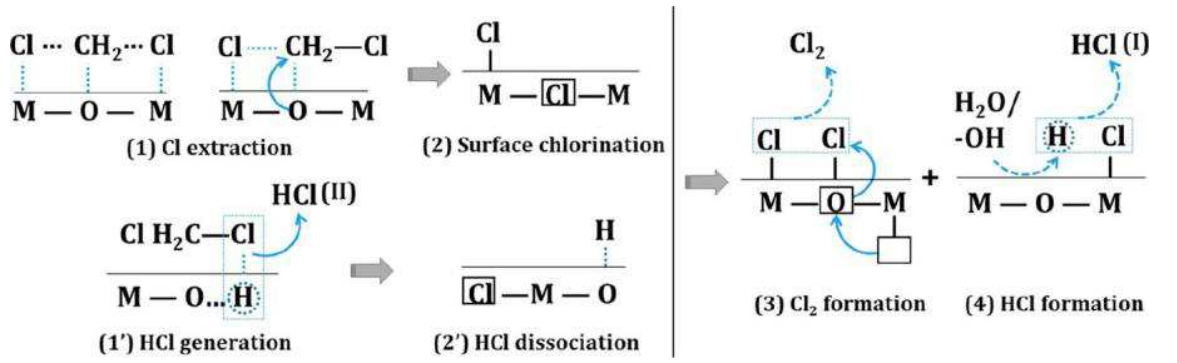

a The migration of lattice oxygen pushed the $\mathrm{Cl}$ atoms out of the occupied sites, and its mobility affects the $\mathrm{Cl}_{2}$ formation in step 3; the structural $-\mathrm{OH}$ or water could react with $\mathrm{Cl}$ to form $\mathrm{HCl}$, and its eff ective supply affects the $\mathrm{HCl}$ formation in step 4.

empty orbital. ${ }^{36,37}$ After phosphoric acid treatment, an intense ammonia desorption peak ca. $214^{\circ} \mathrm{C}$ with a shoulder ca. 303 ${ }^{\circ} \mathrm{C}$ appeared that possibly originates from the exposure of $\mathrm{Mn}\left(\mathrm{IV}\right.$ ) with Lewis acidity at $1628 \mathrm{~cm}^{-1}$ in $\mathrm{NH}_{3}-\mathrm{IR}$ (Figure 5 (b)) and the formation of $\mathrm{LaPO}_{4} \cdot 0.5 \mathrm{H}_{2} \mathrm{O}$ with Brönsted acidity at 1437 and $1668 \mathrm{~cm}^{-138,39}$ in $\mathrm{NH}_{3}-\mathrm{IR}$ (Figure $5(a, b)$ ). In the used catalysts (Figure 5(d)), the total acidity of $\mathrm{La}_{3} \mathrm{Mn}_{2} \mathrm{O}_{7}-\mathrm{P}$ was retained, along with the moderate acidity increasing and the weak acidity decreasing. This result indicated that the acidity in the $\mathrm{La}_{3} \mathrm{Mn}_{2} \mathrm{O}_{7}-\mathrm{P}$ was very stable in DCM oxidation. As reported, ${ }^{23,40}$ the $\mathrm{LaPO}_{4} \cdot 0.5 \mathrm{H}_{2} \mathrm{O}$ associated with $\mathrm{H}_{3} \mathrm{PO}_{4}$ at the surface forming $\mathrm{LaPO}_{4} \cdot 0.5 \mathrm{H}_{2} \mathrm{O}^{\circ}$ $\left(\mathrm{H}_{3} \mathrm{PO}_{4}\right)_{\mathrm{x}}$ that was stable up to $1400{ }^{\circ} \mathrm{C}$. This result explains why the acidity of $\mathrm{La}_{3} \mathrm{Mn}_{2} \mathrm{O}_{7}-\mathrm{P}$ could be stable up to hightemperatures in DCM oxidation. Note that such a highly stabilized Brönsted acidity is particularly beneficial for industrial applications because it can consistently benefit the DCM adsorption ${ }^{41}$ and provide protons for efficient DCM oxidation, even under the frequent thermal shock during operation conditions.

3.6. Cl Removal Capacity Measurements. To confirm the enhanced chlorine removal ability in the $\mathrm{La}_{3} \mathrm{Mn}_{2} \mathrm{O}_{7}-\mathrm{P}$ catalyst, temperature-programmed surface reaction (TPSR) measurements with an inlet of $1000 \mathrm{ppm}$ DCM and 10 vol \% $\mathrm{O}_{2}$ in He were conducted.

For $\mathrm{La}_{3} \mathrm{Mn}_{2} \mathrm{O}_{7}$, as shown in Figure 6, no obvious desorption of $\mathrm{HCl}$ and $\mathrm{Cl}_{2}$ was observed in the first run as the temperature elevated. However, desorption was observed for both as the temperature was maintained at $600{ }^{\circ} \mathrm{C}$. This behavior should be ascribed to the retention of $\mathrm{Cl}$ on the surface of $\mathrm{La}_{3} \mathrm{Mn}_{2} \mathrm{O}_{7}$ in the fast heating process. In the second run, initial temperature for $\mathrm{HCl}$ desorption appeared at approximately 500 ${ }^{\circ} \mathrm{C}$ and that of $\mathrm{Cl}_{2}$ was at approximately $450{ }^{\circ} \mathrm{C}$. This result indicated that the chlorine desorption only occurred at temperatures above $450{ }^{\circ} \mathrm{C}$ in this catalyst and explains why the catalyst inevitably experienced deactivation due to chlorination at temperatures lower than $450{ }^{\circ} \mathrm{C}$ (Figure 1). For $\mathrm{La}_{3} \mathrm{Mn}_{2} \mathrm{O}_{7}-\mathrm{P}$, the $\mathrm{HCl}$ started to desorb at $400{ }^{\circ} \mathrm{C}$ (note: there were a trace amount of $\mathrm{HCl}$ desorbed at $100-350^{\circ} \mathrm{C}$, as shown in the enlarged figure of SI Figure S8), and the $\mathrm{Cl}_{2}$ began desorption at approximately $350{ }^{\circ} \mathrm{C}$ in both runs. Likewise, the $\mathrm{La}_{3} \mathrm{Mn}_{2} \mathrm{O}_{7}-\mathrm{P}$ would not desorb $\mathrm{Cl}$ until the temperature reached $350{ }^{\circ} \mathrm{C}$, in agreement with the activity measurements. Notably, the amount and the desorption rate of chlorine in terms of $\mathrm{HCl}$ or $\mathrm{Cl}_{2}$ from the $\mathrm{La}_{3} \mathrm{Mn}_{2} \mathrm{O}_{7}-\mathrm{P}$ was much higher than those from $\mathrm{La}_{3} \mathrm{Mn}_{2} \mathrm{O}_{7}$ in both runs. This result verified that the $\mathrm{La}_{3} \mathrm{Mn}_{2} \mathrm{O}_{7}-\mathrm{P}$ was indeed efficient for the formation and desorption of $\mathrm{Cl}_{2}$. This desorption ability was eff ectively retained in the used catalyst. The efficient chlorine desorption was also found to suppress the chlorination of intermediate products (i.e., electrophilic chlorination) as the generation of $\mathrm{CHCl}_{3}$ was limited in both the fresh and used $\mathrm{La}_{3} \mathrm{Mn}_{2} \mathrm{O}_{7}-\mathrm{P}$ (SI Figure S9).

3.7. Proposed Reaction Mechanism. In DCM oxidation over the $\mathrm{La}_{3} \mathrm{Mn}_{2} \mathrm{O}_{7}$ type catalysts, a surface chlorination process of the catalyst was observed that had been proven to originate from the formation of $\mathrm{Mn}-\mathrm{Cl}$ bonds (as evidenced by $\mathrm{H}_{2}-\mathrm{TPR}$, XPS and DCM-TPSR analyses), leading to catalyst deactivation. Such a chlorination process was proposed to occur through the extraction of $\mathrm{Cl}$ from DCM molecules at Lewis acidic sites or oxygen vacancies (steps (1-2), Scheme 1). With the temperature elevating, the $\mathrm{Mn}-\mathrm{Cl}$ bond tended to break to form $\mathrm{Cl}_{2}$ or $\mathrm{HCl}$ (as shown in DCM-TPSR, steps (3-4), Scheme 1). The generation of $\mathrm{Cl}_{2}$ was strongly relevant to the mobility of lattice oxygen species, for example, $\alpha^{\prime}-\mathrm{O}$ and $\beta-\mathrm{O}$. The isolated $\mathrm{Cl}$ atoms captured in metal oxide oxygen vacancies preferred to move toward the surface upon heating. This is due to the acceleration of the lattice oxygen migration via the oxygen released from subsurface. This then results in the pushing outward of the superficial trapped $\mathrm{Cl}^{\circ}$ (i.e., the Deacon process), the aggregation of which would form molecular-like species such as $\mathrm{Cl}_{2}$ (step (3), Scheme 1). As such, the accelerated oxygen diff usion due to the shared vertex oxygen removal in $\mathrm{La}_{3} \mathrm{Mn}_{2} \mathrm{O}_{7}-\mathrm{P}$ could favor the $\mathrm{Cl}$ removal from the catalyst surface and thus cause the release of more $\mathrm{Cl}_{2}$ than that of $\mathrm{La}_{3} \mathrm{Mn}_{2} \mathrm{O}_{7}$ (Figure 6). This process would leave vacancies in the subsurface layer according to Amrute et al. and Yang et al., ${ }^{42-44}$ as confirmed by the reduced desorption of subsurface lattice oxygen on the after-test $\mathrm{La}_{3} \mathrm{Mn}_{2} \mathrm{O}_{7}-\mathrm{P}$ in Figure 4(b). Given that the amount of $\mathrm{HCl}$ generation (assisted by proton donor, for example, water and hydroxyl groups) from $\mathrm{La}_{3} \mathrm{Mn}_{2} \mathrm{O}_{7}-\mathrm{P}$ was four times higher than that of $\mathrm{Cl}_{2}$, the dissociative $\mathrm{Cl}$ appears to prefer being trapped by hydroxyl groups or water in the vicinity via hydrogen bonding, forming molecular-like $\mathrm{HCl}$ (step (4), Scheme 1). Similar results in DFT calculations and experiments have been reported by Cen et al. and Dai et al., ${ }^{45,46}$ respectively.

In Scheme 1, steps 1-4 only showed the $\mathrm{HCl}$ formation (hereafter denoted as Type $\mathrm{I} \mathrm{HCl}$ ) originating from the regeneration of chlorinated surface (i.e., the $\mathrm{Cl}$ was extracted from the Lewis sites or oxygen vacancies). However, in the DCM-TPSR measurements (Figure 6), we also observed small amounts of $\mathrm{HCl}$ desorbed at $100-350{ }^{\circ} \mathrm{C}$ (SI Figure S8) in the $\mathrm{La}_{3} \mathrm{Mn}_{2} \mathrm{O}_{7}-\mathrm{P}$ catalyst. This $\mathrm{HCl}$ should originate from the Brönsted acidic sites that provided protons to form $\mathrm{HCl}$ directly (hereafter denoted as Type II HCl, as shown in step 

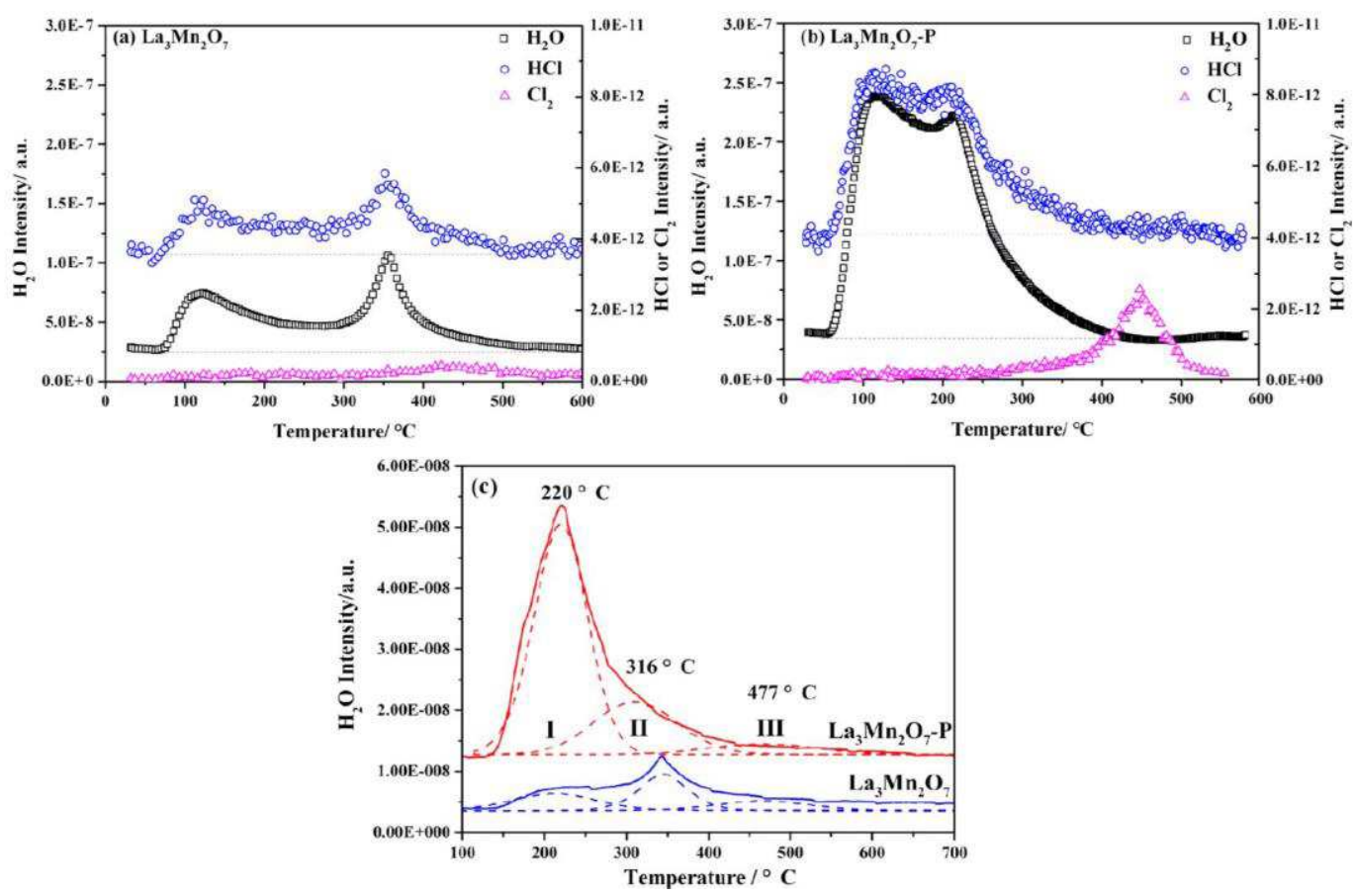

Figure 7. (a) and (b) Profiles of $\mathrm{H}_{2} \mathrm{O}, \mathrm{HCl}$ and $\mathrm{Cl}_{2}$ desorption from $\mathrm{La}_{3} \mathrm{Mn}_{2} \mathrm{O}_{7}$ and $\mathrm{La}_{3} \mathrm{Mn}_{2} \mathrm{O}_{7}-\mathrm{P}$ in a stream of $\mathrm{HCl}(50 \mathrm{ppm}$ in $\mathrm{He})$. The baselines were calibrated by a blank experiment. (c) TPD spectra of $\mathrm{H}_{2} \mathrm{O}(\mathrm{m} / \mathrm{z}=18)$ for $\mathrm{La}_{3} \mathrm{Mn}_{2} \mathrm{O}_{7}$ and $\mathrm{La}_{3} \mathrm{Mn}_{2} \mathrm{O}_{7}-\mathrm{P}$ after purging at 100 ${ }^{\circ} \mathrm{C}$ in $\mathrm{He}$ for $1 \mathrm{~h}$. The peaks correspond to (I) desorption of adsorbed molecular $\mathrm{H}_{2} \mathrm{O}$; (II) associative desorption from hydroxyl group clusters; (III) and its trail from vicinal and spaced hydroxyl groups.
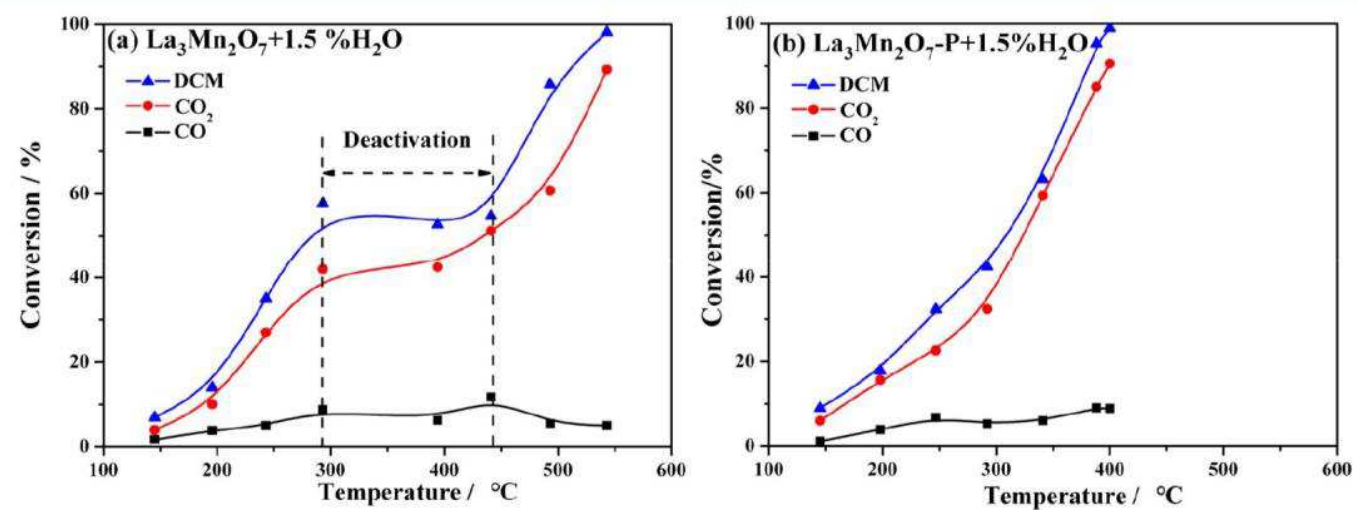

Figure 8. Overall conversion rates of DCM ( ), $\mathrm{CO}_{2}(\circ)$ and $\mathrm{CO}$ ( $)$ ) over the catalysts (a) $\mathrm{La}_{3} \mathrm{Mn}_{2} \mathrm{O}_{7}$ and (b) $\mathrm{La}_{3} \mathrm{Mn}_{2} \mathrm{O}_{7}-\mathrm{P}$ in $\mathrm{DCM}$ oxidation with 1.5 vol \% water vapor.

(1') in Scheme 1). The Type II HCl was even liberated at room temperature once the DCM comes into contact with the $\mathrm{La}_{3} \mathrm{Mn}_{2} \mathrm{O}_{7}-\mathrm{P}$ (SI Figure S10).

To further evaluate the possibility of Type II $\mathrm{HCl}$ dissociation on catalyst surface that might also cause the catalyst chlorination (as shown in step (2') in Scheme 1), $\mathrm{HCl}-\mathrm{TPSR}$ was conducted, in which a flow of $\mathrm{HCl}$ in $\mathrm{He}$ was continuously purged onto the $\mathrm{La}_{3} \mathrm{Mn}_{2} \mathrm{O}_{7}$ and $\mathrm{La}_{3} \mathrm{Mn}_{2} \mathrm{O}_{7}-\mathrm{P}$ catalysts, followed by the recording of $\mathrm{HCl}, \mathrm{Cl}_{2}$, and $\mathrm{H}_{2} \mathrm{O}$ desorption from 100 to $600{ }^{\circ} \mathrm{C}$. As shown in Figure 7, the observation of $\mathrm{Cl}_{2}$ formation suggested that the Type II $\mathrm{HCl}$ was indeed dissociated over the $\mathrm{La}_{3} \mathrm{Mn}_{2} \mathrm{O}_{7}$ and $\mathrm{La}_{3} \mathrm{Mn}_{2} \mathrm{O}_{7}-\mathrm{P}$ catalysts. Hisham et al. ${ }^{47}$ had reported that the $\mathrm{HCl}$ dissociation over metal oxides was an exothermic reaction, which suggested that the dissociation process could occur easily on the $\mathrm{La}_{3} \mathrm{Mn}_{2} \mathrm{O}_{7}$ and $\mathrm{La}_{3} \mathrm{Mn}_{2} \mathrm{O}_{7}-\mathrm{P}$ catalysts. The dissociated $\mathrm{Cl}$ from the Type II $\mathrm{HCl}$ might further cause the catalyst chlorination that would be eventually transferred into type $\mathrm{I} \mathrm{HCl}$ at high temperatures.

In the $\mathrm{HCl}$-TPSR profile, it was also observed that the $\mathrm{HCl}$ desorption coincided with the $\mathrm{H}_{2} \mathrm{O}$ in both the $\mathrm{La}_{3} \mathrm{Mn}_{2} \mathrm{O}_{7}$ and $\mathrm{La}_{3} \mathrm{Mn}_{2} \mathrm{O}_{7}-\mathrm{P}$ catalysts. This suggested that the $\mathrm{HCl}$ might adsorb on the surface $\mathrm{H}_{2} \mathrm{O}$ sites and desorb with the $\mathrm{H}_{2} \mathrm{O}$ at elevated temperatures. We first analyze the different types of $\mathrm{H}_{2} \mathrm{O}$ on the catalyst surface. As shown in Figure 7c, the $\mathrm{H}_{2} \mathrm{O}$-TPD revealed three types of $\mathrm{H}_{2} \mathrm{O}$ in the catalysts. The first peak centered at ca. $220{ }^{\circ} \mathrm{C}$ is ascribed to the adsorbed $\mathrm{H}_{2} \mathrm{O}$ molecules that are directly contacted with the catalyst surface ${ }^{6,45}$ (denoted as Type I); the second peak is associated with the dehydration of structural hydroxyl group clusters (denoted as Type II), and the third peak at $477{ }^{\circ} \mathrm{C}$ and the tail above $500{ }^{\circ} \mathrm{C}$ corresponds to the dehydration of strongly bonded hydroxyl groups ${ }^{48}$ (via the interaction of migrated vicinal and spaced groups, ${ }^{49}$ respectively, denoted as Type III). 

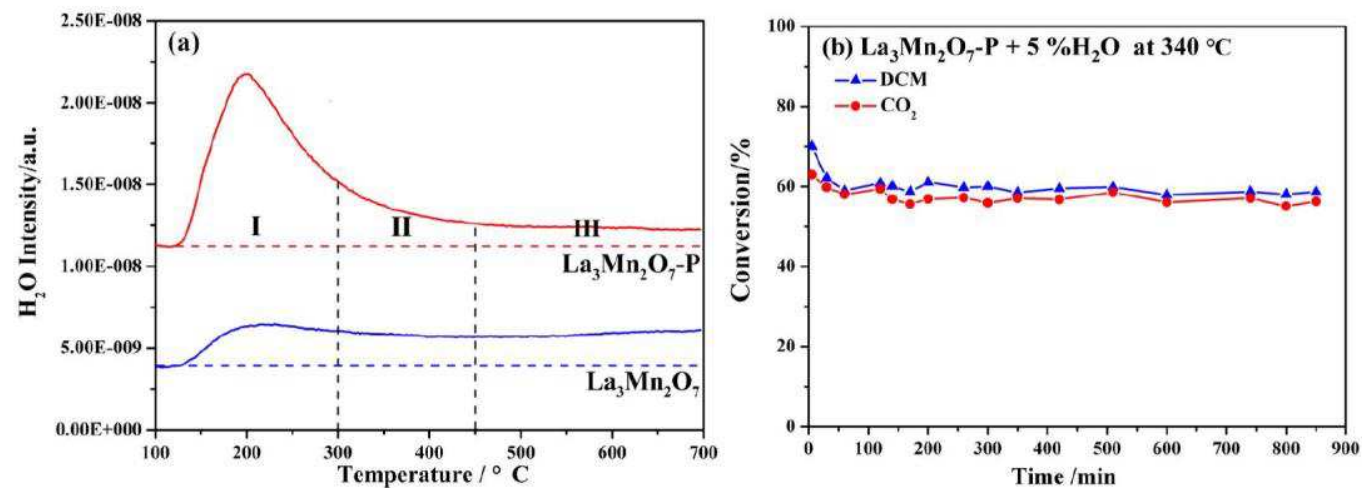

Figure 9. (a) TPD spectra of $\mathrm{H}_{2} \mathrm{O}(\mathrm{m} / \mathrm{z}=18)$ for $\mathrm{La}_{3} \mathrm{Mn}_{2} \mathrm{O}_{7}$ and $\mathrm{La}_{3} \mathrm{Mn}_{2} \mathrm{O}_{7}-\mathrm{P}$ after heating $\left(\right.$ at $500{ }^{\circ} \mathrm{C}$ for $\left.1 \mathrm{~h}\right)$ and rehydration (at $100{ }^{\circ} \mathrm{C}$ for $\left.1 \mathrm{~h}\right)$. Peaks correspond to (I) desorption of adsorbed molecular $\mathrm{H}_{2} \mathrm{O}$; (II) associative desorption from hydroxyl group clusters; (III) and its trail from vicinal and spaced hydroxyl groups. (b) The stability of $\mathrm{La}_{3} \mathrm{Mn}_{2} \mathrm{O}_{7}-\mathrm{P}$ in the presence of vapor for 850 min at $340{ }^{\circ} \mathrm{C}$ in DCM oxidation.

The water clusters (denoted as Type IV) interacting via hydrogen bonding would be removed during sample pretreat-ment step (at the $100{ }^{\circ} \mathrm{C}$ ), which did not appear in the $\mathrm{H}_{2} \mathrm{O}-\mathrm{TPD}$ profile.

Accordingly, the $\mathrm{H}_{2} \mathrm{O}$ desorption peak(s) centered ca. 120$220{ }^{\circ} \mathrm{C}$ in the $\mathrm{HCl}$-TPSR profile (Figure $7 \mathrm{a}, \mathrm{b}$ ) should be ascribed to $\mathrm{H}_{2} \mathrm{O}$ clusters (Type IV) and $\mathrm{H}_{2} \mathrm{O}$ molecules (Type I), and the peak above $300{ }^{\circ} \mathrm{C}$ should be assigned to structural hydroxyl (Type II). According to other studies, ${ }^{50,51}$ the $\mathrm{HCl}$ inclined to dissociate on $\mathrm{H}_{2} \mathrm{O}$ clusters $(n \geq 4)$ or interact with $\mathrm{H}_{2} \mathrm{O}$ molecules via hydrogen bonding. This explained why the $\mathrm{HCl}$ would be desorbed with water simultaneously. In the $\mathrm{H}_{2} \mathrm{O}-\mathrm{TPD}$ profile, it was also noted that the $\mathrm{La}_{3} \mathrm{Mn}_{2} \mathrm{O}_{7}-\mathrm{P}$ produced larger amounts of Type I and Type $\mathrm{II} \mathrm{H}_{2} \mathrm{O}$ than those of the $\mathrm{La}_{3} \mathrm{Mn}_{2} \mathrm{O}_{7}$. The former should be mainly from "zeolitic" water ${ }^{24,31}$ residing in the $\mathrm{LaPO}_{4} \cdot 0.5 \mathrm{H}_{2} \mathrm{O}$ structure and the hydrogen bonding (with the oxygen of $\mathrm{H}_{2} \mathrm{O}$ molecule) at Brönsted acidic sites.

3.8. Water Vapor Eff ect. As either the $\mathrm{H}_{2} \mathrm{O}$ molecules or hydroxyl groups $(-\mathrm{OH})$ could promote $\mathrm{HCl}$ desorption, it is likely that additional water vapor (which exists in many industrial waste gases) might be able to inhibit the catalyst chlorination by facilitating $\mathrm{HCl}$ desorption. Indeed, as shown in Figure 8, with the addition of 1.5 vol \% vapor, the values of $\mathrm{T} 50$ of DCM conversion in $\mathrm{La}_{3} \mathrm{Mn}_{2} \mathrm{O}_{7}$ and $\mathrm{La}_{3} \mathrm{Mn}_{2} \mathrm{O}_{7}-\mathrm{P}$ were both eff ectively reduced to approximately $300^{\circ} \mathrm{C}$, which was nearly $85{ }^{\circ} \mathrm{C}$ lower than those in dry condition. As the temperature increased, $\mathrm{La}_{3} \mathrm{Mn}_{2} \mathrm{O}_{7}$ exhibited a plateau in DCM conversion up to $450{ }^{\circ} \mathrm{C}$ and $\mathrm{La}_{3} \mathrm{Mn}_{2} \mathrm{O}_{7}-\mathrm{P}$ showed a consistently increasing activity. The latter yielded the T90 of DCM conversion at approximately $380{ }^{\circ} \mathrm{C}$ and no obvious deterioration was observed after repeated usage in four runs (SI Figure S11). This activity is comparable to that of the Pt/ $\mathrm{CeO}_{2}-\mathrm{Al}_{2} \mathrm{O}_{3}$ catalyst reported in the literature. ${ }^{52}$

The additional water vapor increased the concentration of molecular $\mathrm{H}_{2} \mathrm{O}$ and hydroxyl groups $(-\mathrm{OH}$, via the dissociation of $\mathrm{H}_{2} \mathrm{O}$ on $\mathrm{M}-(\mathrm{OH})_{n}$ sites, that is, acid-base centers according to Gun'ko et al. and Yin et al. ${ }^{49}, 53$ ) which favored $\mathrm{HCl}$ formation and desorption. This was consistent with many other studies, ${ }^{12,54}$ which all demonstrated that the addition of $\mathrm{H}_{2} \mathrm{O}$ could lead to the generation of more $\mathrm{HCl}$ in $\mathrm{CVOC}$ oxidation. As such, the catalyst chlorination could be inhibited, thus enabling the catalytic activity in DCM oxidation to be maintained.

To verify the cause of the plateau in DCM conversion in the $\mathrm{La}_{3} \mathrm{Mn}_{2} \mathrm{O}_{7}$ catalyst, another $\mathrm{H}_{2} \mathrm{O}$-TPD measurement was conducted in which the catalyst was preheated at $500{ }^{\circ} \mathrm{C}$ for $1 \mathrm{~h}$ and then rehydrated at $100{ }^{\circ} \mathrm{C}$ for $1 \mathrm{~h}$.

As shown in Figure 9a, $\mathrm{La}_{3} \mathrm{Mn}_{2} \mathrm{O}_{7}$ exhibited a lack of Type $\mathrm{I}_{2} \mathrm{O}$ and was inclined to form a stable hydroxyl layer on the surface. The $-\mathrm{OH}$ species appeared to be uniformly distributed as both Type II and Type III $\mathrm{H}_{2} \mathrm{O}$ revealed a plateau-like desorption curve. As reported, ${ }^{55,56}$ the reactivity of hydroxyl groups in the vicinity of $\mathrm{Cl}$ determined the reaction rate for $\mathrm{HCl}$ formation. Therefore, the stable hydroxyl layer would impair the formation of $\mathrm{HCl}$ and the subsequent desorption from the $\mathrm{La}_{3} \mathrm{Mn}_{2} \mathrm{O}_{7}$, leading to the occurrence of a plateau in DCM conversion. This plateau would diminish until the reaction between $\mathrm{Cl}$ and hydroxyl groups recovered at a high temperature (herein, ca. $450{ }^{\circ} \mathrm{C}$ for $\mathrm{La}_{3} \mathrm{Mn}_{2} \mathrm{O}_{7}$, Figure 8).

In $\mathrm{La}_{3} \mathrm{Mn}_{2} \mathrm{O}_{7}-\mathrm{P}$, the presence of "zeolitic" channels in $\mathrm{LaPO}_{4} \cdot 0.5 \mathrm{H}_{2} \mathrm{O}$ would be able to store the additive vapor, and the proton in the Brönsted acidic sites could activate the vapor (via formation of $\mathrm{H}_{3} \mathrm{O}^{+}$or $\mathrm{H}_{5} \mathrm{O}_{2}{ }^{+57}$ ). As such, the Type $\mathrm{I} \mathrm{H}_{2} \mathrm{O}$ in the $\mathrm{La}_{3} \mathrm{Mn}_{2} \mathrm{O}_{7}-\mathrm{P}$ is distinct, which ensured sufficient $\mathrm{H}$ and $\mathrm{H}_{2} \mathrm{O}$ molecules react with dissociated $\mathrm{Cl}$ and desorb the $\mathrm{HCl}$, respectively. Moreover, the Bronsted acidity in the $\mathrm{La}_{3} \mathrm{Mn}_{2} \mathrm{O}_{7}-\mathrm{P}$ catalyst might be capable of hydrolyzing the intermediates (i.e., chloromethoxyl group) and further prevent the chlorination of the catalyst. ${ }^{58}$

It was also found that further increasing the amount of additive water to $5 \mathrm{vol} \%$ did not cause obvious deactivation in DCM oxidation for the $\mathrm{La}_{3} \mathrm{Mn}_{2} \mathrm{O}_{7}-\mathrm{P}$ catalyst (SI Figure S12). The catalyst could retain high DCM conversion after aging at $340{ }^{\circ} \mathrm{C}$ for approximately $850 \mathrm{~min}$ in the presence of $5 \mathrm{vol} \%$ $\mathrm{H}_{2} \mathrm{O}$. This result revealed an excellent water-resistant ability of the catalyst, making it very promising for use in industrial applications (Figure 9b).

\section{ASSOCIATED CONTENT}

* Supporting Information

Catalyst syntheses and characterizations, DCM-TPSR analyses, $\mathrm{HCl}$ generation curves and light-off curves in repeated runs (PDF)

\section{AUTHOR INFORMATION}

Corresponding Author

*E-mail: zbwu@zju.edu.cn. 
ORCID $\odot$

Xiaole Weng: 0000-0003-2997-571X

Zhongbiao Wu: 0000-0003-0182-5971

Notes

The authors declare no competing financial interest.

\section{ACKNOWLEDGMENTS}

This work was financially supported by the National Natural Science Foundation of China (Grant No. 51478418) and the Program for Zhejiang Leading Team of S\&T Innovation (Grant No. 2013TD07).

\section{REFERENCES}

(1) Alvarez-Montero, M. A.; Gomez-Sainero, L. M.; Mayoral, A.; Diaz, I.; Baker, R. T.; Rodriguez, J. J. Hydrodechlorination of chloromethanes with a highly stable $\mathrm{Pt}$ on activated carbon catalyst. J. Catal. 2011, 279 (2), 389-396.

(2) Huang, B.; Lei, C.; Wei, C.; Zeng, G. Chlorinated volatile organic compounds (Cl-VOCs) in environment - sources, potential human health impacts, and current remediation technologies. Environ. Int. 2014, 71, 118-138.

(3) Dai, Q.; Wang, W.; Wang, X.; Lu, G. Sandwich-structured $\mathrm{CeO}_{2} @ Z \mathrm{ZSM}-5$ hybrid composites for catalytic oxidation of 1, 2dichloroethane: An integrated solution to coking and chlorine poisoning deactivation. Appl. Catal., B 2017, 203, 31-42.

(4) Sun, P.; Wang, W.; Dai, X.; Weng, X.; Wu, Z. Mechanism study on catalytic oxidation of chlorobenzene over $\mathrm{Mn}_{\mathrm{x}} \mathrm{Ce}_{1-\mathrm{x}} \mathrm{O}_{2} / \mathrm{H}-\mathrm{ZSM} 5$ catalysts under dry and humid conditions. Appl. Catal., B 2016, 198, 389-397.

(5) Lu, Y. J.; Dai, Q. G.; Wang, X. Y. Catalytic combustion of chlorobenzene on modified $\mathrm{LaMnO}_{3}$ catalysts. Catal. Commun. 2014, 54, 114-117.

(6) Zhang, C.; Wang, C.; Zhan, W.; Guo, Y.; Guo, Y.; Lu, G.; Baylet, A.; Giroir-Fendler, A. Catalytic oxidation of vinyl chloride emission over $\mathrm{LaMnO}_{3}$ and $\mathrm{LaB}_{0.2} \mathrm{Mn}_{0.8} \mathrm{O}_{3}(\mathrm{~B}=\mathrm{Co}, \mathrm{Ni}, \mathrm{Fe})$ catalysts. Appl.

Catal., B 2013, 129, 509-516.

(7) Zhang, C.; Wang, C.; Gil, S.; Boreave, A.; Retailleau, L.; Guo, Y.; Luis Valverde, J.; Giroir-Fendler, A. Catalytic oxidation of 1,2-dichloropropane over supported $\mathrm{LaMnO}_{\mathrm{x}}$ oxides catalysts. Appl. Catal., B 2017, 201, 552-560.

(8) Giraudon, J. M.; Elhachimi, A.; Leclercq, G. Catalytic oxidation of chlorobenzene over Pd/perovskites. Appl. Catal., B 2008, 84 (1-2), 251-261.

(9) Sinquin, G.; Petit, C.; Hindermann, J. P.; Kiennemann, A. Study of the formation of $\mathrm{LaMO}_{3}(\mathrm{M}=\mathrm{Co}, \mathrm{Mn})$ perovskites by propionates precursors: application to the catalytic destruction of chlorinated VOCs. Catal. Today 2001, 70 (1-3), 183-196.

(10) Zhang, C.; Wang, C.; Hua, W.; Guo, Y.; Lu, G.; Gil, S.; Giroir-Fendler, A. Relationship between catalytic deactivation and physicochemical properties of $\mathrm{LaMnO}_{3}$ perovskite catalyst during catalytic oxidation of vinyl chloride. Appl. Catal., B 2016, 186, 173- 183

(11) Cho, C. H.; Ihm, S. K. Development of new vanadium-based oxide catalysts for decomposition of chlorinated aromatic pollutants.

Environ. Sci. Technol. 2002, 36 (7), 1600-1606.

(12) Rivas, B. d.; Lopeź-Fonseca, R.; Gutierreź-Ortiz, M. A.; Gutierrez-Ortiz, J. I. Role of water and other H-rich additives in the catalytic combustion of 1,2-dichloroethane and trichloroethylene. Chemosphere 2009, 75 (10), 1356-1362.

(13) Zhang, Z.; Huang, J.; Xia, H.; Dai, Q.; Gu, Y.; Lao, Y.; Wang, X. Chlorinated volatile organic compound oxidation over $\mathrm{SO}_{4}{ }^{2-} / \mathrm{Fe}_{2} \mathrm{O}_{3}$ catalysts. J. Catal. 2018, 360, 277-289.

(14) Ramesh, K.; Zheng, J. E.; Ling, E. G. Y.; Han, Y.-F.; Borgna, A. Synthesis, Characterization, and Catalytic Activity of Uniformly Crystalline $\mathrm{LaPO}_{4}$ Nanofiber Catalysts for Ethanol Dehydration. J. Phys. Chem. C 2009, 113 (37), 16530-16537.
(15) Bregiroux, D.; Audubert, F.; Bernache-Assollant, D. Densifica-tion and grain growth during solid state sintering of LaPO4. Ceram. Int. 2009, 35 (3), 1115-1120.

(16) Onoda, H.; Nariai, H.; Maki, H.; Motooka, I. Syntheses of various rare earth phosphates from some rare earth compounds. Mater. Chem. Phys. 2002, 73 (1), 19-23.

(17) Wang, W.; Meng, Q.; Yehui Xue, Y.; Weng, X.; Sun, P.; Wu, Z. Lanthanide perovskite catalysts towards oxidation of chloroaromatics: Secondary pollution and modification. J. Catal. 2018, 366, 213-222.

(18) Si, W. Z.; Wang, Y.; Zhao, S.; Hu, F. Y.; Li, J. H. A facile method for in situ preparation of the $\mathrm{MnO}_{2} / \mathrm{LaMnO}_{3}$ catalyst for the removal of toluene. Environ. Sci. Technol. 2016, 50 (8), 4572-4578.

(19) Kawi, S.; Shen, S. C.; Chew, P. L. Generation of Bronsted acid sites on Si-MCM-41 by grafting of phosphorus species. J. Mater. Chem. 2002, 12 (5), 1582-1586.

(20) Du, X.; Zou, G.; Zhang, Y.; Wang, X. A novel strategy for lowtemperature synthesis of Ruddlesden-Popper type layered perovskite $\mathrm{La}_{3} \mathrm{Mn}_{2} \mathrm{O}_{7+\text { delta }}$ for methane combustion. J. Mater. Chem. A 2013, 1 (29), 8411-8416.

(21) Li, J.; Cui, W.; Sun, Y.; Chu, Y.; Cen, W.; Dong, F. Directional electron delivery via a vertical channel between g$\mathrm{C}_{3} \mathrm{~N}_{4}$ layers promotes photocatalytic efficiency. J. Mater. Chem. A 2017, 5 (19), 9358-9364.

(22) Arandiyan, H.; Dai, H.; Deng, J.; Wang, Y.; Sun, H.; Xie, S.; Bai, B.; Liu, Y.; Ji, K.; Li, J. Three-dimensionally ordered macroporous La0.6 $\mathrm{Sr}_{0.4 \mathrm{MnO}}$ supported $\mathrm{Ag}$ nanoparticles for the combustion of methane. J. Phys. Chem. C 2014, 118 (27), 14913-14928.

(23) Lucas, S.; Champion, E.; Bregiroux, D.; Bernache-Assollant, D.; Audubert, F. Rare earth phosphate powders $\mathrm{RePO} 4 \cdot \mathrm{nH}_{2} \mathrm{O}(\mathrm{Re}=$ La, Ce or Y) Part I. Synthesis and characterization. J. Solid State Chem. 2004, 177 (4), 1302-1311.

(24) Colomer, M. T.; Mosa, J. Thermal evolution, second phases, and sintering behavior of $\mathrm{LaPO}_{4} \cdot \mathrm{nH}_{2} \mathrm{O}$ nanorods prepared by two different chemical synthesis routes. Ceram. Int. 2015, 41 (6), 8080-8092.

(25) Liu, J.; Lu, B.; Liu, J.; Zhang, Y.; Wei, Y. The hindering function of phosphate on the grain growth behavior of nanosized zirconia powders calcined at high temperatures. Ceram. Int. 2011, 37 (3), 843-849.

(26) Lee, C.; Jeon, Y.; Hata, S.; Park, J.-I.; Akiyoshi, R.; Saito, H.; Teraoka, Y.; Shul, Y.-G.; Einaga, H. Three-dimensional arrangements of perovskite-type oxide nano-fiber webs for effective soot oxidation. Appl. Catal., B 2016, 191, 157-164.

(27) Irusta, S.; Pina, M. P.; Menendez, M.; Santamaria, J. Catalytic combustion of volatile organic compounds over Labased perovskites. J. Catal. 1998, 179 (2), 400-412.

(28) Zhao, B.; Ran, R.; Sun, L.; Guo, X.; Wu, X.; Weng, D. NO catalytic oxidation over an ultra-large surface area $\mathrm{LaMnO}_{3+\text { delta }}$ perovskite synthesized by an acid-etching method. RSC Adv. 2016, 6 (74), 69855-69860.

(29) Bond, G. C.; Sadeghi, N. Catalysed destruction of chlorinated hydrocarbons. J. Appl. Chem. Biotechnol. 1975, 25 (4), 241-248.

(30) Maiti, D.; Daza, Y. A.; Yung, M. M.; Kuhn, J. N.; Bhethanabotla, V. R. Oxygen vacancy formation characteristics in the bulk and across different surface terminations of $\mathrm{La}(1-\mathrm{x}) \mathrm{Sr}_{\mathrm{x}} \mathrm{Fe}_{(1-\mathrm{y})} \mathrm{Co}_{\mathrm{y}} \mathrm{O}_{(3-\text { delta) }}$ perovskite oxides for $\mathrm{CO}_{2}$ conversion. J. Mater. Chem. A 2016, 4 (14), 5137-5148.

(31) Mesbah, A.; Clavier, N.; Elkaim, E.; Szenknect, S.; Dacheux, $\mathrm{N}$. In pursuit of the rhabdophane crystal structure: from the hydrated monoclinic $\mathrm{LnPO}_{4} \cdot 0.667 \mathrm{H}_{2} \mathrm{O}$ to the hexagonal $\mathrm{LnPO}_{4}(\mathrm{Ln}=\mathrm{Nd}, \mathrm{Sm}$, Gd, Eu and Dy). J. Solid State Chem. 2017, 249, 221-227.

(32) Zhang, C.; Guo, Y.; Guo, Y.; Lu, G.; Boreave, A.; Retailleau, L.; Baylet, A.; Giroir-Fendler, A. $\mathrm{LaMnO}_{3}$ perovskite oxides prepared by different methods for catalytic oxidation of toluene. Appl. Catal., B 2014, 148, 490-498.

(33) Kagomiya, I.; Jimbo, K.; Kakimoto, K.-i. Distribution change of oxygen vacancies in layered perovskite type $(\mathrm{Sr}, \mathrm{La})_{\mathrm{n}+1} \mathrm{Fe}_{\mathrm{n}} \mathrm{O} 3 \mathrm{n}+1$ $(\mathrm{n}=3)$. J. Solid State Chem. 2013, 207, 184-189. 
(34) Kagomiya, I.; Jimbo, K.; Kakimoto, K.-i.; Nakayama, M.; Masson, O. Oxygen vacancy formation and the ion migration mechanism in layered perovskite $(\mathrm{Sr}, \mathrm{La})_{3} \mathrm{Fe}_{2} \mathrm{O}_{7 \text {-delta. }}$ Phys. Chem. Chem. Phys. 2014, 16 (22), 10875-10882.

(35) Si, W.; Wang, Y.; Peng, Y.; Li, J. Selective dissolution of Asite cations in $\mathrm{ABO}_{(3)}$ perovskites: A new path to high-performance catalysts. Angew. Chem., Int. Ed. 2015, 54 (27), 7954-7957.

(36) Pena, M. A.; Fierro, J. L. G. Chemical structures and performance of perovskite oxides. Chem. Rev. 2001, 101 (7), 1981- 2017.

(37) Liu, L.; Song, Y.; Fu, Z.; Ye, Q.; Cheng, S.; Kang, T.; Dai, H. Effect of preparation method on the surface characteristics and activity of the Pd/OMS-2 catalysts for the oxidation of carbon monoxide, toluene, and ethyl acetate. Appl. Surf. Sci. 2017, 396, 599- 608 .

(38) Barzetti, T.; Selli, E.; Moscotti, D.; Forni, L. Pyridine and ammonia as probes for FTIR analysis of solid acid catalysts. J. Chem. Soc., Faraday Trans. 1996, 92 (8), 1401-1407.

(39) Taouli, A.; Klemt, A.; Breede, M.; Reschetilowski, W. Acidity investigations and determination of integrated molar extinction coefficients for infrared absorption bands of ammonia adsorbed on acidic sites of MCM-41. Stud. Surf. Sci. Catal. 1999, 125 (10), 307-314.

(40) Afanasiev, P. Non-aqueous preparation of $\mathrm{LaPO}_{4}$ nanoparticles and their application for ethanol dehydration. RSC Adv. 2015, 5 (53), 42448-42454.

(41) Lopez-Fonseca, R.; Aranzabal, A.; Gutierrez-Ortiz, J. I.; Alvarez-Uriarte, J. I.; Gonzalez-Velasco, J. R. Comparative study of the oxidative decomposition of trichloroethylene over H-type zeolites under dry and humid conditions. Appl. Catal., B 2001, 30 (3-4), 303-313.

(42) Amrute, A. P.; Mondelli, C.; Moser, M.; Novell-Leruth, G.; Lopez; N.; Rosenthal, D.; Farra, R.; Schuster, M. E.; Teschner, D.; Schmidt, T.; Pereź-Ramírez, J. Performance, structure, and mechanism of $\mathrm{CeO}_{2}$ in $\mathrm{HCl}$ oxidation to $\mathrm{Cl}_{2}$. J. Catal. 2012, 286, 287-297.

(43) Yang, Y.; Zhang, S.; Wang, S.; Zhang, K.; Wang, H.; Huang, J.; Deng, S.; Wang, B.; Wang, Y.; Yu, G. Ball milling synthesized $\mathrm{MnO}_{\mathrm{X}}$ as highly active catalyst for gaseous POPs removal: Significance of mechanochemically induced oxygen vacancies. Environ. Sci. Technol. 2015, 49 (7), 4473-4480.

(44) Amrute, A. P.; Mondelli, C.; Hevia, M. A. G.; PereźRamírez, J. Mechanism-Performance relationships of metal oxides in catalyzed $\mathrm{HCl}$ oxidation. ACS Catal. 2011, 1 (6), 583-590.

(45) Dai, Q.; Yin, L.-L.; Bai, S.; Wang, W.; Wang, X.; Gong, X.-Q.; Lu, G. Catalytic total oxidation of 1,2-dichloroethane over $\mathrm{VO}_{\mathrm{x}} / \mathrm{CeO}_{2}$ catalysts: Further insights via isotopic tracer techniques. Appl. Catal., B 2016, 182, 598-610.

(46) Cen, W.; Liu, Y.; Wu, Z.; Liu, J.; Wang, H.; Weng, X. Cl species transformation on $\mathrm{CeO}_{2}(111)$ surface and its effects on CVOCs catalytic abatement: A first-principles investigation. J. Phys. Chem. C 2014, 118 (13), 6758-6766.

(47) Hisham, M. W. M.; Benson, S. W. Thermochemistry of the Deacon process. J. Phys. Chem. 1995, 99 (16), 6194-6198.

(48) Afzal, S.; Quan, X.; Zhang, J. L. High surface area mesoporous nanocast $\mathrm{LaMO}_{3}(\mathrm{M}=\mathrm{Mn}, \mathrm{Fe})$ perovskites for efficient catalytic ozonation and an insight into probable catalytic mechanism. Appl. Catal., B 2017, 206, 692-703.

(49) Gun'ko, V. M.; Zarko, V. I.; Chuikov, B. A.; Dudnik, V. V.; Ptushinskii, Y. G.; Voronin, E. F.; Pakhlov, E. M.; Chuiko, A. A. Temperature-programmed desorption of water from fumed silica, titania, silica/titania, and silica/alumina. Int. J. Mass Spectrom. Ion Processes 1998, 172 (3), 161-179.

(50) Lee, C. T.; Sosa, C.; Planas, M.; Novoa, J. J. A theoretical study of the ionic dissociation of $\mathrm{HF}, \mathrm{HCl}$, and $\mathrm{H}_{2} \mathrm{~S}$ in water clusters. J. Chem. Phys. 1996, 104 (18), 7081-7085.

(51) Ault, B. S.; Pimentel, G. C. Infrared spectrum of the waterhydrochloric acid complex in solid nitrogen. J. Phys. Chem. 1973, 77 (1), 57-61.
(52) Chen, Q. Y.; Li, N.; Luo, M. F.; Lu, J. Q. Catalytic oxidation of dichloromethane over $\mathrm{Pt} / \mathrm{CeO}_{2}-\mathrm{Al}_{2} \mathrm{O}_{3}$ catalysts. Appl. Catal., B 2012, 127 (17), 159-166.

(53) Yin, H.; Zhao, S.; Zhao, K.; Muqsit, A.; Tang, H.; Chang, L.; Zhao, H.; Gao, Y.; Tang, Z. Ultrathin platinum nanowires grown on single-layered nickel hydroxide with high hydrogen evolution activity. Nat. Commun. 2015, 6, 6430.

(54) Zhang, S.; You, J.; Kennes, C.; Cheng, Z.; Ye, J.; Chen, D.; Chen, J.; Wang, L. Current advances of VOCs degradation by bioelectrochemical systems: A review. Chem. Eng. J. 2018, 334, 2625- 2637.

(55) Zhai, Y.; Pierre, D.; Si, R.; Deng, W.; Ferrin, P.; Nilekar, A. U.; Peng, G.; Herron, J. A.; Bell, D. C.; Saltsburg, H.; Mavrikakis, M.; Flytzani-Stephanopoulos, M. Alkali-stabilized $\mathrm{Pt}-\mathrm{OH}_{\mathrm{X}}$ species catalyze low-temperature water-gas shift reactions. Science 2010, 329 (5999), 1633-1636.

(56) Subbaraman, R.; Tripkovic, D.; Chang, K.-C.; Strmcnik, D.; Paulikas, A. P.; Hirunsit, P.; Chan, M.; Greeley, J.; Stamenkovic, V.; Markovic, N. M. Trends in activity for the water electrolyser reactions on $3 \mathrm{~d} \mathrm{M}(\mathrm{Ni}, \mathrm{Co}, \mathrm{Fe}, \mathrm{Mn}) \mathrm{hydr}(\mathrm{oxy})$ oxide catalysts. Nat. Mater. 2012, 11 (6), 550-557.

(57) Laasonen, K.; Klein, M. L. Ab initio molecular dynamics study of hydrochloric acid in water. J. Am. Chem. Soc. 1994, 116 (25), 11620-11621.

(58) Zhang, L.; Liu, S.; Wang, G.; Zhang, J. Catalytic combustion of dichloromethane over NaFAU and HFAU zeolites: a combined experimental and theoretical study. React. Kinet., Mech. Catal. 2014, 112 (1), 249-265. 